\title{
The Temple of Besakih, Sukuh, and Cetho: The Dynamics of Cultural Heritage in the Context of Sustainable Tourism Development in Bali and Java
}

\author{
I Ketut Ardhana ${ }^{1, *}$, I Ketut Setiawan ${ }^{1} \&$ Sulanjari $^{1}$ \\ ${ }^{1}$ Faculty of Art, Universitas Udayana, Denpasar, Indonesia \\ *Correspondence: Faculty of Art, Universitas Udayana, Denpasar, Indonesia. Tel: 62-812-3864-9192. E-mail: \\ phejepsdrlipi@yahoo.com
}

Received: January 2, 2019

Accepted: January 14, 2019 Online Published: January 22, 2019

doi:10.5430/wjss.v6n1p26

URL: https://doi.org/10.5430/wjss.v6n1p26

\begin{abstract}
Besakih is one of the biggest Hindu temple in Bali and the temple of Sukuh and Cetho are the Hindu temple that still existing in Central Java. These temples have their similarity and differences in the context of how to develop the sustainable tourist development in Indonesia. However, there are not many experts who understand about the cultural relation between the temple of Besakih in Bali, Sukuh and Cetho in Central Java.

This becomes important since the indigenization process that took place in the past of history in the two islands are significant to be understood in terms of social cultural, economic and political development in which their influences can be seen at the modern and postmodern Balinese culture. The development of Balinese temple of Besakih can be considered in the $11^{\text {th }}$ century, while for Sukuh and Cetho temple after the fall of Majapahit kingdom in the $15^{\text {th }}$ century. Therefore, it can be said that Hindu did not only develop in Bali, but also in Central Java, in which the development of Hindu for the beginning already took place indeed in the $7^{\text {th }}$ to $8^{\text {th }}$ in the context of Hindu Mataram namely in the era of king Sanjaya.

The main questions that are need to be addressed in this paper are how was the process of the end of Majapahit culture that caused the cultural indigenization in the central Java such as shown in the temple of Sukuh and Cetho? Secondly, in which cultural context that occurred since the Javanese kingdoms did not influence the strength of the Hindu culture in the later period? Thirdly, how can it be compared the similarity and the difference between the indigenization in Bali and in Central Java?and lastly how the Balinese and the Javanese interprete their own culture in terms of local wisdom? By addressing these questions, it is expected to have a better understanding on how both communities can strengthen their own culture in the context of their prosperity.
\end{abstract}

Keyword: indigenization, Besakih, Sukuh, Cetho, Balinese and Javanese culture

\section{Introduction}

One of the impacts of globalization to ask us to think about on how we can improve the prosperity of the local people, since the globalization process has caused positive and negative impacts. It accordingly causes the emergence of a variant related to the functions and roles of the temple. From the archaeological and historical accounts it is noted that a temple is considered as place for praying and due to the globalization it adds other function such as economic function due to the tourist industry development (Ardhana, 2016). Therefore, a temple can improve the prosperity of the local communities where the temple is located.

Despite of that it does not mean that the economic function will weaken the cultural heritages, in which by introducing this function cause the Balinese cultural heritages have been recognized as a world cultural heritage and also as important world tourist destination, particularly in order to promote the temple as holy places and will appreciated not only in terms of religiousity, but also profant values (Ardhana, 2017). From this perspective, it can be said that tourist sector is not only encourage the economic aspect, but also creating new job opportunities.

In general, the Hindu Javanese temple has the same function as in Bali as happened in the Dutch colonial era, 
Islamization, and Indonesian independence, though there are some changes due to the globalization processes Cf. (Ramstedt, 1999 see also: Covarrubias, 1986). Due to the willingness to encourage the economic aspect it is understood that economic aspect is related to the tourist industry. From this picture it can be considered that there are some different perspectives between the temple in Bali and in Java.

At this time, the total number of population in the Berjo Village is around 41 members and in the surrounding temple are only nine (9) members. It seems that the limited members do not actively in managing the tourist industry sectors, though it is noted that most of them already informed about the tourism industry since 2003 . This can be understood since the total number of population who reside in the surrounding temple is very limited and most of them work as the tea farmers. Around the temple it is noted there are around seven (7) coffee shops and the tourist facilities are managed by the local people. In addition to this, the government income from the entrance tickets to the temple from the Tourism Office Bureau in the Central Java, managed by the BPCB Jawa Tengah (Interview with Sugeng, local officer of the Dinas Pariwisata Kabupaten Karanganyar, September 15, 2017, see also: Yoeti, 1985). The communities in the Cetho village for instance is around $80 \%$ of them are Hindu adherents, who preserve and maintain the temple as a place for Hindu worship.

In order to understand the issues regarding "the Temple of Besakih, Sukuh, and Cetho: The Dynamics of Cultural Heritage in the Context of Sustainable Tourism Development in Bali and Java" the analysis will be focused on firstly: the geographical and historical background of the temple Besakih, Sukuh and Cetho, secondly: Besakih, Sukuh, and Cetho as cultural heritage, thirdly: Besakih, Sukuh, and Cetho as cultural heritage, fourth: Besakih, Sukuh, and Cetho as ritual and tourist destination. By discussing these issues, it is expected to have a better understand about how the local people in Bali and Java in particular, and in Indonesia in general, to encourage the strengthening of their local culture to be promoted to the both domestic and international tourists in order to achieve the goal in terms of prosperity of the local people (Ardhana 2010, Ardhana, 2012).

\section{Geographical and Historical Background of the Temple Besakih, Sukuh and Cetho}

The Besakih temple in Bali is located very close to the Mount Agung, in the Rendang sub-district, in Karangasem regncy, in which is considered as one of the world tourist destination and also has significant function in the context of ancestor temple (Stuart-Fox, 2010: 125, see also: Surpha, 1979). The Besakih temple was built in the $11^{\text {th }}$ century, while for Sukuh and Cetho temple were built after the fall of Majapahit kingdom in the $15^{\text {th }}$ century. The Besakih temple symbolizes the Tri Hita Karana consep in which there is a balance and harmony between man and God, man and man and man with its nature. The temple of Sukuh, well known as Candi Sukuh is a complex of Hindu temple, located very close to the Mount Lawu in the Ngargoyoso sub-district and Karanganyar regency in Central Java. Meanwhile, the temple of Cetho is located in the Cetho area, Gumeng village, Jenawi sub-district, Karanganyar regency, Central Java Province.

The temple of Sukuh is considered as the youngest Hindu temple in Indonesia and it was built in the $15^{\text {th }}$ century in the era of Princess Ratu Suhita from 1429 to 1446. While, the temple of Cetho is located nearby temple of Sukuh and moreless $11 \mathrm{~km}$. The temple of Sukuh itself was found by Johnson, a resident from Surakarta in 1815, that Java was under the General Governor of Stamford Raffles. It is noted that the temple of Sukuh has already promoted to the tourists in the Dutch colonial era.

The temple of Sukuh was built to the west orientation, consists of three levels symbolize the way to enter the perfectness. These levels are symbolized with the Indian epics namely Bima Suci, Ramayana, Garudeya, Cuddhamala, and Swargarohanaparwa reliefs. This means also on how the people would enter the heaven. It is important to note that what happened with the Besakih temple, the temple of Sukuh, and Cetho were built in the context of Megalithicum period, are symbolized with the so called Punden Berundak (in the form of terraces) as sign of the previous period from the prehistoric time. With this concept, it means that the upper area is considered as the most holy place to the Mount of Lawu (circa $1976 \mathrm{~m}$ from the sea level), in which is believed that the peak of Mount Lawu to be a places for ancestors. In this context there is acceleration between the Hindu religion and the Balinese culture, in which the mountain as the places for Gods. There is different condition in compared to the temple of Sukuh namely the Cetho temple. The temple of Cetho which was built in the $15^{\text {th }}$ century as a Hindu worship in the end period of Majapahit and still using as a place for ritual and religious activities both for the Hindu Javanese and the local Javanese believers or the Kejawen, who are the followers of the old Javanese culture and tradition.

The Cetho temple was found at the first time by Van de Vlies who was a Dutch archeology in 1842. According to local tradition, this temple was built in the context of protection against the magic power, called Tolak Bala or 
Ruwatan. It can be understood since in the downfall of the Majapahit kingdom in the $15^{\text {th }}$ century, there were social, economic and political turbulences in the context of domestic affairs of the Majapahit kingdom. Due to this unstable political situation, this place accordingly used by the last king of Majapahit, Bravijaya as a place for meditation. It is believed that the king was in here to avoid meeting with his son, Raden Patah who had been adhered to Islam.

In addition to this, according to the local information based on the types of the stones and statues it is believed that the Cetho temple was built before the downfall of Majapahit (interview with Winarno, the temple manager September 15, 2017 in the Cetho temple). In addition to this, based on the spiritual aspects as a foundation of this temple this becomes a reason why we can in this temple about the local tradition and Hindu Javanese culture. Therefore, the function of this temple can be used as a tourist destination for culture and ecotourism.

\section{Besakih, Sukuh, and Cetho as Cultural Heritage}

In the peak of the Sukuh temple as places for offerings in which is used as the place for meditation. The uniqueness of the Sukuh temple, that this temple has many reliefs and statues in the form of lingga and yoni as symbols for penis and vagina. This indicates that the Sukuh temple as a Hindu temple in which lingga and yoni symbolize the philosophical values in the man life based on the Hindu beliefs. In addition to this, the lingga and yoni reliefs are related to the examination to a woman on how she is loyal to her husband. It is believed that for a woman, who was examined she had to walk to pass the lingga-yoni. If she was successful to pass and did not show to her body it meant that she was passed the examination.

It is already mentioned previously that the Besakih, Sukuh and Cetho as place for Hindu worships, based on the reliefs that exist in the building of those temples. The richness of the local tradition that is mixed with the local myths will encourage positively the function of the Sukuh temple. One of the uniqueness of the Sukuh temple becomes more interesting for young people to visit this temple in relation to the myths. This can be seen at the style of the building, forms of the statues and messages in the form of penis and vagina that emerged at the end of the Majapahit period. Though the temple of Sukuh and Cetho as a Hindu temple in Central Java, however the intensity of the visitors who visit the temples have decreased, and it is even the most people who reside in the surrounding of the temples are non-Hindu and this picture is different in compared to the temple of Besakih in Bali.

In the Javanese culture it is difficult to separate between local culture or adat and Hindu religion. This becomes the main reason to develop the temple area of Sukuh and Cetho to be a tourist destination. There are similarities between the temple of Besakih, Sukuh, and Cetho. The Hindu holyday namely the Galungan, the Kuningan, and the Nyepi Day are celebrated by the Hindu adherents in the temple of Cetho, by conducting ritual and Hindu ceremony in the temple. In the Besakih temple is commonly held once a year in relation the biggest ceremony in Bali, the Eka Dasa Rudra or centennial purification of the universe (Eiseman, 2000: 235, see also: Vickers, 1989: 167). In the celebration they wear the Javanese cloths. This indicates that they are the Javanese Hindu who descended from the Majapahit. However, the temple of Cetho does not have any philosophical and religious or ritual link with the temple of Besakih. In other words, it means that in the context of religious concept the Hindu communities do not have any link and religious worship in the family temples in Bali. They do pray and worship only to the God in the context of Trimurti (interview with Jero Mangku in the temple of Cetho, September 15, 2017).

In addition to the religious ritual, some people come to the temple of Cetho for instance to hold Modosionan that is a ceremony based on the Javanese calender, namely Tuesday or Selasa Kliwon. Later it is followed with the togetherness or Bersih Desa, which means to hold ceremony in accordance with the thankful to the God and their ancestors, since they are successful in managing their agricultural sectors. In certain days, there are many Balinese visitors to come to this place in order to hold a ritual or ceremony activities (Interview with Winarno in the temple of Cetho, September 5, 2017).

\section{Besakih, Sukuh, and Cetho as Ritual and Sustainable Tourist Development}

The temple of Besakih, Sukuh and Cetho are located in convenient places regarding the tourist development. Besakih is one of the tourist destinations that have been promoted to the domestic and international tourists and the temples of Sukuh and Cetho temples are very close to the Solo city and often visited by domestic tourists from Bali and Jakarta. Most of the tourists who visit the Sukuh and Cetho temple are: (1). Cultural and eco-tourism in which the tourists need to enjoy the beauty of the cultural richness and cultural heritage, and ecological or environment aspects (2). Some researches that have been carried out by the local and the foreign tourists (3). Ritual, in which the tourists hold ritual ceremony most of them are the Balinese, the Kejawen communities from inside or outside the village of Sukuh. 
Most of them visit these temples on Saturday and Sunday, especially in the holydays around June, July and August that can reach 1000 tourists a month. (Interview with Gunawan, September 15, 2017 in the temple of Sukuh).

In encouraging the tourists visit to the Sukuh and Cetho temples the Central Java local government through the Cultural Division (Dinas Pariwisata, Balai Pelestarian Cagar Budaya, the BPCB) hold many trainings and guiding on how to sold the souvenirs to the tourists. In this context, it is expected that the local people should be involved in the tourist industry and preserve and maintain the self belonging, called Handarbeni. The aims is to maintain that the temple of Sukuh as a cultural heritage that consisting of local wisdom. Therefore, the efforts to preserve the temple of Sukuh is not only a responsibility of the local government (Dinas Pariwisata/ BPCB), but also for the people in the region. It is important to note, since the Sukuh temple as tourist assets that it can contribute to improve the income of the local people (Interview with Sugeng, staf member of BPCB the Temple of Sukuh, September 15, 2017).

Regarding the sustainable tourist development, those temples have represented the strengthening of the local heritage, Hindu religion and the diversity. The temple of Besakih that is rich in terms of Hindu religion and the local culture both tangible and intangible culture become interesting cultural aspects in Bali. In addition to this, the Besakih temple has its function and role as a center for worship in Bali and outside Bali (Widia, 1979/ 1980). It is accordingly the Besakih develop as a live monument. It is possible, since the dominant of the people in Bali is the Balinese who are adherents of Hindu.

The ability to anticipate the impacts of globalization in the context of dynamic of tourist development we can see in the temple of Besakih in which Bali has been recognized as one of the world tourist destination. The function of the temple Besakih as the Hindu worship affects this temple as a magnet for the tourist both domestic and international tourist destination. The Hindu adherents from outside Karangasem, and even from outside Bali come to the Besakih temple to ask holy water called, Nunas Tirtha. As a center for Hindu worship from all regions in Indonesia, the temple of Besakih symbolizes as the center for unity and diversity. Therefore, the temple of Besakih can strength the Hindu religion and also to develop the sustainable tourist development in Bali in particular, and in Indonesia in general.

In contrast to this, it is hard for the temple of Sukuh, in which most of the people who reside in the surrounding of the people are Muslim adherents. This means that they are different in compared the temple of Sukuh which is related to the Hindu temple. In compared to the temple of Sukuh especially regarding the concept of live monument, the temple Cetho is possible, since most of the people who reside in the surrounding temple of Cetho are the Hindu adherents. To anticipate such condition, the BPCB as a representative of the local cultural Division (Dinas Pariwisata) to empower the local human resources to work as security to maintain and preserve the cultural heritage in the temple of Sukuh and Cetho.

Therefore, it is a way on how to ask the people to have self belonging to their cultural heritage, Handarbeni to strengthen their ancestor cultural heritage. As a result, the effort to maintain the temple of Sukuh and Cetho as a representation of the Hindu Javanese culture can be maintained in terms of its function and roles.

\section{Conclusion}

The main issue to develop tourist industry in the temple of Besakih, Sukuh and Cetho is to try to involve to the local people in terms of self belonging the cultural sites, in order to be able to improve their prosperity. In compared to the tourist management it seems that the management of the temple Besakih more advanced than the temple of Sukuh and Cetho). However, the management of the Sukuh and Cetho seems to be organized at the recent time.

There is a difference in terms of how to develop the temple of Sukuh and Cetho. It is important to note that if the people who reside in the surrounding temple have the same tradition it is easier to develop it in terms of sustainable tourist development, since they have the same religious spirit. However, both temple of Sukuh and Cetho have already strengthened the Hindu cultural heritage, and also strengthening the unity and diversity. However in compared to the temple of Sukuh, the temple of Cetho has more potentiality to be developed as a living monument since the people who reside in the surrounding temple of Cetho, are the Hindu adherents, though not similar to the temple of Besakih which has already recognized as one of the world tourist destination.

In contrast to the temple of Sukuh, in the temple of Cetho seems to be able to be done since most of the people who reside in there are the Hindu adherents. It means that the local people perceive that the temple of Cetho is important for them as a Hindu ritual and ceremony activities. This is one important aspect that need to be developed in terms of the function and role of temple. As living monument it is accordingly easier to develop the cultural and religious 
sites to be promoted as sustainable tourist development. In this case, the temple of Cetho can be created as a favorite place to be visited by the Balinese who conduct the spiritual journey to this temple, called Tirtayatra.

To develop religious tradition and cultural heritage is significant for the temple of Cetho that has its uniqueness and characteristic in terms of spiritual and high culture and also the important Hindu place for worshipping not only foe the Hindu Javanese, but also for other Hindu adherents fron all of the Indonesian regions. By promoting this religious sites and cultural heritage, it is accordingly will be able to develop the temples in terms of improving their prosperity based on the sustainable tourist development.

\section{References}

Ardhana I. Ketut. (2010). "Cultural Heritage in Bali”, in Bali Internship Fieldschool 2015: Towards Sustainable Cultural Landscape of Subak System. Gianyar $2^{\text {nd }}-8^{\text {th }}$ August.

Ardhana I. Ketut. (2016). "Archeological Sites in the Context of Heritage Cities". Paper presented at the 2nd International Conference of SEAMEO Regional Centre for Archaeology and Fine Arts (SPAFA), Bangkok, May 30 to June 2.

Ardhana I. Ketut. (2017). Religious Teachings on Sustainability in the Context of Hinduism in Bali. International Journal of Sociology. (Web of Science) Istanbul-Turkey.

Ardhana I. Ketut. (2012). Cultural Relationships between India and Indonesia: Viewing from the Collective Memories. Paper presented at the India-ASEAN Academic Seminar on "India and Indonesia-Shared History \& Culture and Opportunities for Deepening People to People Contacts held by Indian Embassy in Jakarta, Cultural Consulate of India in Denpasar and University of Udayana, in Denpasar Bali, 30 October.

Covarruabias, Miguel. (1986). Island of Bali. London and New York: KPI.

Eiseman, Fred B. (2000). Bali Sekala \& Niskala. Volume I: Essays on Religion, Ritual and Art. Singapore: Priplus.

Ramstedt, Martin. (1999). Hinduismus und Naturkulte. In Bernhard Dahm dan Roderich Ptak (eds.), Sudostasien-Handbuch: Geschichte, Gesellschaft, Politik, Wirtschaft, Kultur. Munchen: Verlag CH Beck.

Stuart Fox, David J. (2010). Pura Besakih: Pura, Agama, dan Masyarakat Bali. Jakarta: KITLV Press.

Surpha I. Wayan. (1979). Menyongsong Karya Eka Dasa Rudra di Pura Besakih. Surabaya: Yayasan Bank Naskah Indonesia.

Vickers, Adrian. (1989). Bali: A Paradise Created. Singapore: Periplus Editons.

Widia, Wayan. (1979/1980). Pura Agung Besakih. Denpasar: Proyek Sasana Budaya Bali Direktorat Jenderal Kebudayaan Departemen Pendidikan dan Kebudayaan.

Informan:

\begin{tabular}{|c|l|l|l|}
\hline No & \multicolumn{1}{|c|}{ Name } & \multicolumn{1}{|c|}{ Address } & \multicolumn{1}{|c|}{ Profession } \\
\hline 1. & Budiartha, Wayan & Besakih village & $\begin{array}{l}\text { Archive Officer (Pegawai Kantor } \\
\text { Kearsipan dan Perpustakaan) }\end{array}$ \\
\hline 2. & Gunawan & Sukuh village & $\begin{array}{l}\text { Local manager (Juru Pelihara Candi } \\
\text { Sukuh) }\end{array}$ \\
\hline 3. & Kartika, Wayan & Besakih village & $\begin{array}{l}\text { Local officer (Pegawai Kantor Kepala } \\
\text { Desa Besakih) }\end{array}$ \\
\hline 4. & Sudarsana, Wayan & Besakih village & $\begin{array}{l}\text { Local officer (Pegawai Kantor Kepala } \\
\text { Desa Besakih) }\end{array}$ \\
\hline 5. & Sugeng & Sukuh village & $\begin{array}{l}\text { Local officer (Pegawai Dinas Pariwisata } \\
\text { Kabupaten Karangasem) }\end{array}$ \\
\hline 6. & $\begin{array}{l}\text { Suwardi, Heri. Jero } \\
\text { Mangku }\end{array}$ & Cetho village & $\begin{array}{l}\text { Local Hindu priest (Pemangku Candi } \\
\text { Cetho) }\end{array}$ \\
\hline 7. & Winarno & Cetho village & Juru Pelihara Candi Cetho \\
\hline
\end{tabular}

